ZOOLOGIA 32(5): 351-359, October 2015

http://dx.doi.org/10.1590/S1984-46702015000500004

\title{
Factors determining the structure of fish assemblages in an Amazonian river near to oil and gas exploration areas in the Amazon basin (Brazil): establishing the baseline for environmental evaluation
}

\author{
Igor David Costa ${ }^{1} \&$ Carlos Edwar de Carvalho Freitas ${ }^{2, *}$
}

\author{
${ }^{1}$ Departamento de Engenharia de Pesca, Fundação Universidade Federal de Rondônia. Rua da Paz 4376, \\ 76916-000 Presidente Médici, RO, Brazil.E-mail: igorbiologia@yahoo.com.br \\ ${ }^{2}$ Departamento de Ciências Pesqueiras, Universidade Federal do Amazonas. Avenida General Rodrigo Otávio 3000, \\ 69077-000 Manaus, AM, Brazil. \\ “Corresponding author. E-mail: cefreitas@ufam.edu.br
}

\begin{abstract}
Determining the significance of biotic and abiotic factors in the structuring of fish assemblages in freshwater environments is an important question in ecology, particularly in view of environmental changes caused by man. In this paper we sought to identify the factors responsible for the composition and abundance of fish species collected with gill nets in six locations near ports in forest clearance areas opened up for oil and natural gas exploration (Petrobras Pedro Moura Base) in the Urucu River, during drought and flood cycles. In all, 923 individuals from 23 families and 82 species were collected, totalling a biomass of $182,244 \mathrm{~g}$. The most abundant species during the flood season were Bryconops alburnoides (Kner, 1858) and Dianema urostriatum (Miranda Ribeiro, 1912); in the drought season, the predominant species were Osteoglossum bicirrhosum (Cuvier, 1829) and Serrasalmus rhombeus (Linnaeus, 1766). The species with the greatest biomass during the flood season were Pellona castelnaeana (Valenciennes, 1847), S. rhombeus and Pellona flavipinis (Valenciennes, 1847). During the drought season, the predominant species was $O$. bicirrhosum. When both periods were analysed together, electrical conductivity, water transparency and dissolved oxygen were the most important factors. The species Hemisorubim platyrhynchos (Valenciennes, 1840), O. bicirrhosum, Chaetobranchus flavenscens Heckel, 1840, Geophagus proximus (Castelnau, 1855) were strongly related to high values of conductivity, $\mathrm{pH}$ and water current velocity during the drought season, as well as Serrasalmus altispinis Merckx, Jégu \& Santos, 2000, Triportheus albus Cope, 1872, Triportheus angulatus (Spix \& Agassiz, 1829) and Brycon melanopterus (Cope, 1872) that were associated with less depth and width in the drought season whereas P. castelnaeana, D. urostriatum, Rhytiodus argenteofuscus Kner, 1858 and Sorubim lima (Bloch \& Schneider, 1801) were mainly associated with high transparency and dissolved oxygen during the flood season.
\end{abstract}

KEY WORDS. Abiotic; floodplain; biological organization; hydrocarbons.

Elucidation of the processes that determine the composition and structure of natural communities and the prevalence of abiotic or biotic factors in these processes remains an important challenge in ecology (CHESSON \& Huntly 1997, JACKson et al. 2001). While some studies carried out in tropical rivers have identified non-random assemblage patterns that could be associated with abiotic factors (RodrígUes \& LeWIS 1997), others have shown the influence of biotic interactions, such as predation and competition, on assemblage structure (FreITAS et al. 2010). In large tropical rivers, the importance of abiotic and biotic factors can vary depending on the scale considered (Freitas et al. 2013) and the period of the hydrological cycle (Winemiller 1989).

Aquatic ecosystems throughout the world are facing continuous threats from human activities. The resulting changes they suffer exert a detrimental influence on aquatic communi- ties (DUDGEON et al. 2006) and may be responsible for the extinction of numerous species. According to Agostinho et al. (2005), the main causes of fish biodiversity loss in aquatic ecosystems can be grouped into five major categories: (1) competition for water and subsequent water abstraction; (2) habitat alteration; (3) pollution from different sources (heavy metals, pesticides and domestic and industrial wastewater); (4) the introduction of exotic species; and (5) commercial exploitation. Changes in the species richness and composition of fish communities in rivers with different levels of environmental impact can be determined in many ways. Fish community attributes (e.g., species richness and diversity) provide basic information about qualitative changes (MAGURRAN 2003), but emergent attributes (structure, composition and organization) allow the effects of environmental changes on communities to be better assessed (KARR 1981). 
The Amazon River basin harbours the world's greatest diversity of freshwater fish (Freitas et al. 2010). To date, most studies of the diversity of Amazonian fish have been concentrated in the floodplains adjacent to large rivers (CRAMPTON 1999, Freitas \& Garcez 2004, Siqueira-Souza \& Freitas 2004), and there are few reports on the ichthyofauna of the middle and upper courses of tributaries of the Amazon River (Silvano et al. 2000).

An oil and natural gas production facility was built on the upper stretch of the Urucu River, a tributary of the right bank of the Solimões River, in 1988, and a pipeline that crosses the forest in parallel with the Urucu River has connected the facility with a harbor in the Solimões River since the end of the 1980s. Taking into account the scarce information about fish fauna in the upper stretches of tributaries of the Amazonas River, and the complete inexistence of data from the Amazonian fish assemblages inhabiting the water bodies surrounding the oil and natural gas plant, we tested the hypothesis that the structure of fish assemblages differ among the studied periods due to the change of limnological variables from port activities over a stretch of that watershed.

This study evaluated the influence of environmental variables on the structure of fish assemblages in a stretch of the Urucu River during the drought and flood seasons and could constitute a baseline to identify changes due environmental pressures mediated by the oil and gas exploration plant.

\section{MATERIAL AND METHODS}

The study was conducted in the Urucu River, near the Evandro 1, Evandro 2, and Urucu harbors, which supply the Petrobras Pedro Moura Oil and Gas Exploration Base. The area is located in the municipality of Coari, in the state of Amazonas. The Urucu River $\left(04^{\circ} 53^{\prime} \mathrm{S}, 65^{\circ} 11^{\prime} \mathrm{W}\right)$ is a right-bank tributary of the Solimões River and one of the main tributaries of the Coari Lake. The water in the river is classified as black. However, during the flood season, it is almost white and is referred to locally as 'toldada'. The region is flat with gently rolling hills and acidic soil, and the climate is classified as tropical, with virtually no winter. Although rainfall is distributed throughout the year, the months of January to April and July to September have higher and lower rainfall, respectively.

Fish collections in the Urucu River were performed in April and August 2008, during the flood and drought season, respectively. The collection points, in a longitudinal (upstreamdownstream) sequence, were: a control point (PCONT) $\left(4^{\circ} 51^{\prime} 20.7^{\prime \prime} \mathrm{S}, 65^{\circ} 20^{\prime} 53.2^{\prime \prime} \mathrm{W}\right)$ located upstream of the three ports; a point downstream of Urucu port (DPU) (4 $4^{\circ} 50^{\prime} 59.3^{\prime \prime}$, $65^{\circ} 20^{\prime} 37.4^{\prime \prime} \mathrm{W}$ ) located $500 \mathrm{~m}$ from the port; a point opposite Evandro 2 port (PE2) $\left(4^{\circ} 45^{\prime} 47.9^{\prime \prime} \mathrm{S}, 65^{\circ} 02^{\prime} 46.6^{\prime \prime} \mathrm{W}\right)$; a point upstream of Evandro 2 port (UE2) $\left(4^{\circ} 45^{\prime} 42^{\prime \prime} \mathrm{S}, 65^{\circ} 02^{\prime} 37.4^{\prime \prime} \mathrm{W}\right)$; a point downstream of this same port (DE2) $\left(4^{\circ} 45^{\prime} 26.4^{\prime \prime} \mathrm{S}\right.$, $\left.65^{\circ} 02^{\prime} 38.7^{\prime \prime} \mathrm{W}\right)$; and a point downstream of Evandro 1 port (DE1) $\left(4^{\circ} 45^{\prime} 02.2^{\prime \prime} \mathrm{S}, 65^{\circ} 02^{\prime} 42.6^{\prime \prime} \mathrm{W}\right)$ (Fig. 1). With the excep- tion of DPU, all collection points were located $1 \mathrm{~km}$ upstream or downstream of their respective ports (Fig. 1). Eight sets of standardized $2 \times 20 \mathrm{~m}$ fishing nets with mesh sizes varying from 30 to $100 \mathrm{~mm}$ (between opposite knots) were used. Sampling effort was standardized and collections were carried out for 13 hours continuously at each sampling point from 6:00 am to 7:00 pm. Fish were screened and identified according to Nelson (2006) and Ferreira et al. (1998) and by experts from the National Amazonian Research Institute (INPA). The biomass in grams of each species was calculated using a $0.01 \mathrm{~g}$ accuracy digital scale. All the fish were sorted, identified and fixed in $10 \%$ formalin and preserved in $70 \%$ ethanol. Some of the specimens were deposited in the ichthyological collection at the INPA (Vouchers: INPA-32193, INPA-32201, INPA-32186, INPA-32187, INPA-32188, INPA-32184, INPA-32190, INPA32194, INPA-32195, INPA-32197, INPA-32199, INPA-32183, INPA-32178, 32200-INPA and INPA-32175).

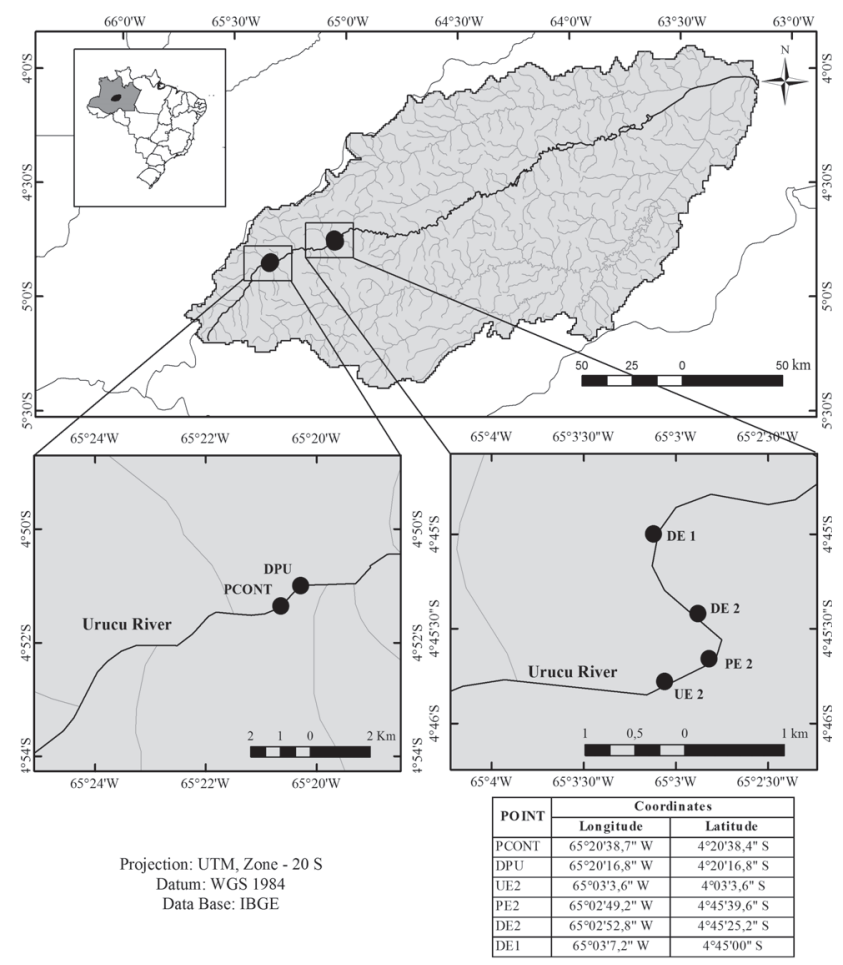

Figure 1. Study area showing the sampling areas and sampling points.

The following limnological variables were measured at the subsurface at each sampling point with a DIGIMED DM4P digital potentiometer: temperature $\left({ }^{\circ} \mathrm{C}\right)$, electrical conductivity $(\mu \mathrm{S} / \mathrm{cm}), \mathrm{pH}$ and dissolved oxygen $\left(\mathrm{mgO}_{2} / \mathrm{L}\right)$. The following measurements were also taken: river depth $(\mathrm{m})$, with the aid of a weighted tape measure; water transparency $(\mathrm{cm})$, with a Secchi disk; and river width (m), with a GPS. Water current velocity 
was measured at each sampling point with a General Oceanics 2030R mechanical flow meter with a 6-digit odometer-style counter and minimum velocity reading of $10 \mathrm{~cm} / \mathrm{s}$.

As aliphatic hydrocarbons (AHCs) are potential contaminants from oil and natural gas plants, the concentration and source (petrogenic or biogenic) of these pollutants in open water was determined using a specific technique for aliphatic hydrocarbons ( $\mathrm{n}$-alkanes from $\mathrm{n}-\mathrm{C}_{12}$ to $\mathrm{n}-\mathrm{C}_{40}$ and the two isoprenoids pristane and phytane). One liter of water was collected from each sampling point, and extraction was carried out by mechanical agitation using a funnel with dichloromethane. The extract was then cleaned up and fractionated using liquid chromatography and hexane as the mobile phase. Aliphatic hydrocarbon content was determined by gas chromatography with flame ionization detection (GC-FID). An internal/recovery standard was added before the samples were extracted to check the efficiency of the methodologies used - modified from EPA 8270 (1986)

The Shapiro-Wilks and Levene tests were used with the limnological variables to test for normality and homogeneity of variance, respectively, to determine whether parametric test t or non-parametric Mann-Whitney U test could be appropriate to compare the seasonal measures. To identify differences in fish fauna between periods of drought and flood, the analysis of similarities (ANOSIM) proposed by CLARKE \& GREEN (1988) was used for numerical abundance and biomass data. We used the Morisita-Horn index (MAGURRAn 2003) as a quantitative similarity measure, as this is almost independent of sample size and species richness (WOLDA 1981). Canonical correlation analysis (CCA) was used with species with abundance greater than three individuals to quantify the influence of environmental variables on the distribution of fish species in periods of drought and flood. The Monte Carlo test was also performed (5.999 permutations) to determine the significance of each environmental variable. The data were previously log-transformed (log $\mathrm{x}+1$ ). CCA and ANOSIM were performed with PAST 2.17 soft- ware (HAMmER et al. 2001). Inferential analyses were considered significant when $\mathrm{p} \leqslant 0.05$.

\section{RESULTS}

Temperature $(\mathrm{U}=19.0 ; \mathrm{p}=0.48)$, transparency $(\mathrm{U}=11.5$; $\mathrm{p}=0.09)$, dissolved oxygen $(\mathrm{t}=1.77 ; \mathrm{p}=0.10)$, water current velocity $(\mathrm{U}=17.5 ; \mathrm{p}=0.37)$, river width $(\mathrm{t}=1.27 ; \mathrm{p}=0.22)$ and concentrations of aliphatic hydrocarbons $(U=21.0 ; p=0.65)$ did not vary between the hydrological seasons. Conductivity was higher during the drought season $(\mathrm{U}=0.001, \mathrm{p}=0.001)$ than during the flood season, and $\mathrm{pH}(\mathrm{t}=-5.98, \mathrm{p}=0.0006)$ and river depth $(t=4.16, p=0.001)$ were lower in the drought season than in the flood season (Table 1). Aliphatic hydrocarbon levels did not indicate contamination from petrogenic sources. The nalkanes with the highest concentration $\left[\mathrm{n}-\mathrm{C}_{29}\right.$ (drought) and n$\mathrm{C}_{31}$ (flood)] originated from the combustion of plant material.

The fish collections comprised 923 individuals distributed in 7 orders, 23 families and 82 species. Characiformes were the dominant group (61\%), followed by Siluriformes (20\%), while the orders Clupeiformes, Osteoglossiformes, Perciformes, Beloniformes and Pleuronectiformes accounted for less than 10\% of the total captured. The most abundant species during the flood season were Bryconops alburnoides (Kner, 1858) ( $\mathrm{n}=64$, 13\%) and Dianema urostriatum (Miranda Ribeiro, 1912) $(\mathrm{n}=63$, $13 \%)$; in the drought season, the predominant species were Osteoglossum bicirrhosum (Cuvier, 1829) ( $\mathrm{n}=55,12 \%)$ and Serrasalmus rhombeus (Linnaeus, 1766) $(n=44,9 \%)$. The biomass in the flood season was $76,100 \mathrm{~g}$ and in the drought season, $106,144 \mathrm{~g}$, totalling $182,244 \mathrm{~g}$. The species with the greatest biomass during the flood season were Pellona castelnaeana (Valenciennes, 1847) (14,235 g, 20\%), Serrasalmus rhombeus (11,680 g, 16\%), Pellona flavipinnis (Valenciennes, 1836) (73,55 g, 10\%) and Calophysus macropterus (Lichtenstein, 1819) (7,230 g, $10 \%)$. During the drought season, the predominant species was Osteoglossum bicirrhosum (45,506 g, 47\%) (Appendix 1).

Table 1. Limnological data analyzed at collection points in the Urucu River in the flood and (drought) seasons. (T) Temperature, (Trans.) transparency, $(\mathrm{CD})$ conductivity, $(\mathrm{pH})$ Hydrogen potential, $\left(\mathrm{O}_{2}\right)$ dissolved oxygen, (Vel.) water current velocity, (Wid) width of the river, (Dpt) depth, (CAH) concentrations of Aliphatic hydrocarbons, $(\mathrm{A})$ average collection points, $(\mathrm{SD})$ standard deviation, $\left({ }^{*}\right) \mathrm{p}<0.05$.

\begin{tabular}{|c|c|c|c|c|c|c|c|c|}
\hline \multirow{2}{*}{ Limnological variables } & \multicolumn{6}{|c|}{ Collection points } & \multirow{2}{*}{ A } & \multirow{2}{*}{ SD } \\
\hline & PCONT & DPU & UE2 & PE2 & DE2 & DE1 & & \\
\hline $\mathrm{T}\left(\mathrm{C}^{\circ}\right)$ & $26.4(26.5)$ & $25.9(25)$ & $25(26.6)$ & $25(25)$ & $26(25)$ & $26(25)$ & $25.7(25.4)$ & $0.5(0.7)$ \\
\hline Trans $(\mathrm{cm})$ & $77(65)$ & $72(53)$ & $83(54)$ & $78(54)$ & $75(72)$ & $83(84)$ & $78.5(65.8)$ & $4.2(12.8)$ \\
\hline $\mathrm{CD}\left(\mu \mathrm{Scm}^{-1}\right)^{*}$ & $8.4(34.7)$ & $8.4(34.6)$ & $9.5(35.2)$ & $9.3(35.2)$ & $9.6(34.6)$ & $9.6(34.8)$ & $9.1(34.8)$ & $0.5(0.2)$ \\
\hline $\mathrm{pH}^{*}$ & $5.7(6.2)$ & $5.3(6.2)$ & $5.9(6.4)$ & $6.0(6.5)$ & $5.8(6.3)$ & $5.9(6.4)$ & $5.7(6.3)$ & $0.2(0.1)$ \\
\hline $\mathrm{O}_{2}\left(\mathrm{mgO}_{2} / \mathrm{L}\right)$ & $5.8(6.1)$ & $6.0(6.7)$ & $5.8(5.4)$ & $5.4(4.5)$ & $6.0(4.3)$ & $5.8(3.5)$ & $5.7(5)$ & $0.2(1.1)$ \\
\hline Vel $(m / s)$ & $0.3(0.5)$ & $0.3(0.5)$ & $0.3(0.2)$ & $0.3(0.5)$ & $0.3(0.5)$ & $0.3(0.2)$ & $0.3(0.4)$ & $0(0.1)$ \\
\hline $\operatorname{Wid}(\mathrm{m})$ & $20(15)$ & $25(26)$ & $62(35)$ & $50(44)$ & $50(42)$ & $75(38)$ & $48.8(34.7)$ & $19.4(10.6)$ \\
\hline Dpt $(m)^{*}$ & $5.1(1)$ & $5.9(1)$ & $8.6(4.3)$ & $7.5(2)$ & $11.2(7.7)$ & $8.5(2.9)$ & $7.7(3)$ & $1.9(2.3)$ \\
\hline $\mathrm{CHA}\left(\mu \mathrm{g} \mathrm{L}^{-1}\right)$ & $0.1(2.9)$ & $1.4(0)$ & $0(0.3)$ & $18.6(0.1)$ & $7.0(0)$ & $0.1(4.1)$ & $3.9(1.1)$ & $6.95(1.7)$ \\
\hline
\end{tabular}


ANOSIM based on biomass did not show significant differences between flood and drought seasons $(r=0.15, p=0.10$, 9999 permutations). However, ANOSIM based on abundance revealed a greater variation in this parameter in the drought season than in the flood season $(r=0.22, p=0.04,9999$ permutations). The first two CCA axes for the flood and drought seasons explained $49.47 \%$ of the distribution of species (Fig. 2). CCA 1 explained $30.47 \%$ of the variance based on conductivity, transparency, $\mathrm{pH}$, dissolved oxygen and water current velocity; and CCA 2 explained $19.90 \%$ of the variance associated with the variables width and depth. The Monte Carlo test indicated that the first two axes derived from the CCA were significant $(\mathrm{p}<0.05)$ (Table 2$)$. Hemisorubim platyrhynchos (Valenciennes, 1840), Osteoglossum bicirrhosum, Chaetobranchus flavenscens Heckel, 1840 and Geophagus proximus (Castelnau, 1855 ) were strongly related to high values of conductivity, $\mathrm{pH}$ and water current velocity during the drought season,

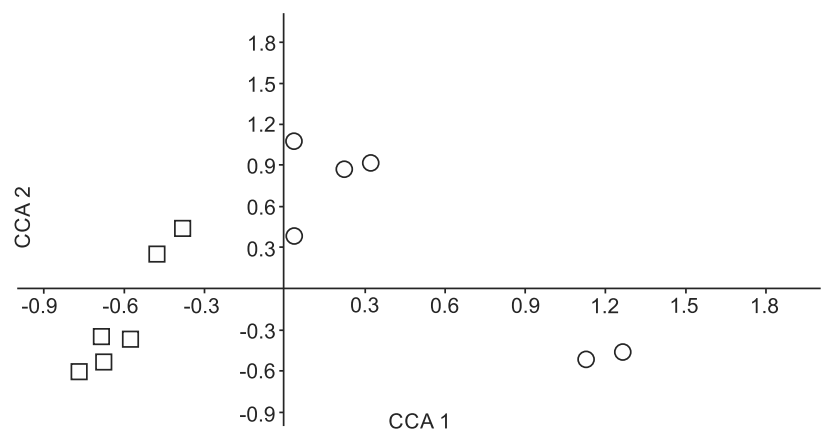

Figure 2. Scores for sampling points on the first two axes of the Canonical Correlation Analysis (CCA) in the drought/flood period: $(\square)$ flood period and $(\bigcirc)$ drought period.

Table 2. Results of the Canonical Correlation Analysis for the occurrence of fish species and key environmental variables in periods of drought and flood in the Urucu River, Municipality of Coari, AM, Brazil.

\begin{tabular}{lrr}
\hline & \multicolumn{2}{c}{ Drought/Flood } \\
\cline { 2 - 3 } & Cnvironmental variables & CCA2 \\
\hline Temperature $\left(\mathrm{C}^{\circ}\right)$ & -0.37 & 0.27 \\
Transparency $(\mathrm{cm})$ & -0.52 & -0.26 \\
Electrical conductivity $\left(\mu \mathrm{Scm}^{-1}\right)$ & 0.82 & 0.44 \\
$\mathrm{pH}$ & 0.75 & 0.12 \\
Dissolved oxygen $\left(\mathrm{mgO}_{2} / \mathrm{L}\right)$ & -0.59 & 0.05 \\
Water velocity $(\mathrm{m} / \mathrm{s})$ & 0.51 & -0.05 \\
River width $(\mathrm{m})$ & -0.12 & -0.81 \\
Depth (m) & -0.52 & -0.73 \\
Concentration of hydrocarbons $\left(\mu \mathrm{L}^{-1}\right)$ & -0.39 & -0.06 \\
\% Explained variance & 30.47 & 19.90 \\
\% Accumulated variance & 39.47 & 49.47 \\
Monte Carlo simulation $(5999$ permutations) $-\mathrm{p}$ & 0.01 & 0.00 \\
\hline
\end{tabular}

as well as Serrasalmus altispinis Merckx, Jégu \& Santos, 2000, Triportheus albus Cope, 1872, Triportheus angulatus (Spix \& Agassiz, 1829) and Brycon melanopterus (Cope, 1872) that were associated with less depth and width in the drought season, whereas $P$. castelnaeana, D. urostriatum, Rhytiodus argenteofuscus Kner, 1858 and Sorubim lima (Bloch \& Schneider, 1801) were mainly associated with high transparency and dissolved oxygen during the flood season (Table 3 ).

\section{DISCUSSION}

Several studies have shown that the composition, structure and diversity of fish assemblages in flooded areas are correlated with abiotic factors such as dissolved oxygen (SAINT-PAUL $\&$ SOARES 1987), temperature, $\mathrm{pH}$, conductivity and habitat complexity; geomorphological features such as depth (STEWART et al. 2002, Freitas et al. 2013), transparency (Rodrígues \& Lewis 1997, SúAreZ et al. 2001), lake area (SúAREZ et al. 2001), connectivity and distance between water bodies (FreITAS \& GARCEZ 2004); and biotic factors such as predation and competition (SAINTPAul et al. 2000).

Predictably, changes in fish community structure associated with flood and drought events are related to variations in transparency and depth, which are strongly correlated variables, primarily because of the increase in turbidity resulting from the resuspension of sediment from the river bottom to the water column (Hamilton \& Lewis 1990). Water transparency, a variable that governs the visibility of the water column, determines the dominance of a large number of taxa and types of piscivorous animals in lakes during the drought season (Rodríguez \& LEwIs 1997). In general, Characiformes and cichlids use visual orientation towards the daylight: they have large eyes and live in well-lit places such as surface waters (LowEMcConnell 1999). Similarly, Clupeiformes reduce their dependence on the optical system in the water column by adapting to life on the surface, which they do by taking advantage of a number of body features, such as silvery scales, a laterally compressed body, upturned jaws and a flat dorsal profile. In contrast, several species of Siluriformes and Gymnotiformes have nocturnal habits, as well as sensorial adaptations to low light (Lowe-McConnell 1999), and are found predominantly in turbid waters.

The association of $H$. platyrhynchos with conductivity during the drought season is explained by the increase in ion concentration during this period. This is due to the high turbidity (low light intensity) in the water column caused by the decrease in the volume of water (Esteves 1998). Siluriformes have sensory adaptations to low light levels and are found predominantly in turbid waters (Lowe-McConnell 1999), while species such as O. bicirrhosum, C. flavenscens and G. proximus are more related to water current velocity. KIKUCHI \& UIEDA (1998) observed that the highest rates of water current velocity are found in the flood season, and the lowest during the drought. 
Table 3. Scores on axis 1 and axis 2 based on the matrix of species assemblage composition and the matrix of habitat variables in periods of drought and flood in the Urucu River, Municipality of Coari, AM, Brazil.

\begin{tabular}{|c|c|c|}
\hline Species & CCA 1 & CCA 2 \\
\hline Pellona castelnaeana (Valenciennes, 1847) & -1.344080 & -1.411710 \\
\hline Dianema urostriatum (Miranda Ribeiro, 1912) & -1.256870 & -1.349400 \\
\hline Rhytiodus argenteofuscus kner, 1858 & -1.250630 & -1.057100 \\
\hline Sorubim lima (Bloch \& Schneider, 1801) & -1.187530 & -0.727260 \\
\hline Pristobrycon striolatus (Steindachner, 1908) & -1.176140 & -0.413100 \\
\hline Raphiodon vulpinus Spix \& Agassiz, 1829 & -1.168580 & -0.509860 \\
\hline Lycengraulis batesii (Günther, 1868) & -1.162720 & -1.060510 \\
\hline Hypoptopoma cf. gulare Cope, 1878 & -1.140400 & -0.887850 \\
\hline Cynodon gibbus Spix \& Agassiz, 1829 & -1.105250 & -0.003700 \\
\hline Pinirapus pirinanpus (Spix \& Agasiz, 1829) & -1.072580 & -0.029480 \\
\hline Pygocentrus nattereri Kner, 1858 & -0.909090 & -0.273610 \\
\hline Pellona flavipinnis (Valenciennes, 1836) & -0.898830 & 0.036199 \\
\hline Bryconops alburnoides (Kner, 1858) & -0.770940 & -0.943670 \\
\hline Brycon cf. pesu Müller Troschel, 1845 & -0.631250 & 0.951399 \\
\hline Serrasalmus rhombeus (Linnaeus, 1766) & -0.459250 & 0.409816 \\
\hline Hemiodus semitaeniatus (Kner, 1858) & -0.421950 & 0.394312 \\
\hline Myleus rubrypinnis (Müller \& SchomburgK, 1841) & -0.404910 & 1.042980 \\
\hline Moenkhausia lepidura (Kner, 1858) & -0.331460 & 1.575480 \\
\hline Leporinus agassizi Steindacherner, 1876 & -0.226540 & 0.894908 \\
\hline Calophysus macropterus (Lichtenstein, 1819) & -0.101490 & -0.279850 \\
\hline Plasgioscion squamosissimus (Heckel, 1840) & -0.052310 & 0.363431 \\
\hline Pimelodus blochii (Valenciennes, 1840) & -0.049800 & 0.542570 \\
\hline Chalceus erythrurus (Cope, 1870) & 0.047424 & 1.774320 \\
\hline Rineloricaria sp. & 0.159718 & 1.669650 \\
\hline Agoniates halecinus (Müller \& Troschel, 1845) & 0.292889 & -0.682450 \\
\hline Brycon melanopterus (Cope, 1872) & 0.315085 & 2.866150 \\
\hline Serrasalmus altispinis Merckx, Jégu \& Santos, 2000 & 0.376206 & 3.238450 \\
\hline Triportheus albus Cope, 1872 & 0.502797 & 2.690570 \\
\hline Triportheus angulatus (Spix \& Agassiz, 1829) & 0.595742 & 2.746460 \\
\hline Hemiodus unimaculatus (Bloch, 1794) & 0.622580 & -0.878750 \\
\hline Caenotropus labyrinthicus (Kner, 1858) & 0.632348 & 0.648210 \\
\hline Boulengerella maculata (Valenciennes, 1 & 1.025970 & -0.335890 \\
\hline Curimata inornata Vari, 1989 & 1.238580 & 0.507683 \\
\hline Curimata vittata $($ Kner, 1858$)$ & 1.238580 & 0.507683 \\
\hline Cichla sp. & 1.420020 & -0.000190 \\
\hline Acestrhorhynchus falcirostris (Cuvier, 1819) & 1.516500 & -0.199120 \\
\hline Hoplias malabaricus (Bloch, 1794) & 1.594580 & -0.406270 \\
\hline Geophagus proximus (Castelnau, 1855) & 1.905290 & -0.727420 \\
\hline Chaetobranchus flavenscens Heckel, 1840 & 1.987890 & -0.658540 \\
\hline Osteoglossum bicirrhosum (Cuvier,1829) & 2.420040 & -1.484380 \\
\hline Hemisorubim platyrhynchos (Valenciennes, 1840) & 2.444300 & -1.470070 \\
\hline
\end{tabular}

Thus, we infer that the association of these species with water current velocity is a consequence of their sedentary habits, as the various collection points analyzed are transformed into large backwater areas during the drought season.
Clupeiformes, such as Pellona flavipinis (Valenciennes, 1847), are morphologically specialized for foraging near the surface (GoulDING 1980). The distribution of species associated with transparency can be interpreted based on the following evolutionary adaptations: (1) extremely good visual orientation in non-piscivorous species in environments with low transparency, specifically at the surface of the water column because of the higher luminosity. Dianema urostriatum, one insectivorous species (Rers 2003), can be resident on this floodplain, colonizing the flooded forest adjacent during flood season.

The association of T. albus and T. angulatus with less depth and width during the drought season could be related to the seasonal feeding patterns of these species. Triportheus angulatus remains into the lakes during flood period. However, when the water level is reducing, almost adults start coming out of the lake before the total isolation, performing lateral migration out of the floodplain (Yамамото et al. 2004) resulting that the highest abundance occurs during receding waters and drought period (SoARes \& Junk 2000). According to Yamamoto et al. (2004) in the drought season there is a clear reduction in the availability of food, insects and plant material being the most consumed by the species thus $T$. angulatus eat such food items that are more available in this lean period (ҮАмамото et al. 2004). As well as the species of Triportheus, B. melanopterus presents omnivorous habit (SANTOS et al. 2006), demonstrating a considerable range of food items consumed by the group, which involves consumption this from plant debris, terrestrial and aquatic insects to fish and small vertebrates (AlbRecht et al. 2009). The Piranha S. altispinis, like most members of this group, consumes fish however fruits, seeds and invertebrates are part of the diet of constant or occasional basis (SANTOS et al. 2006). According to Yамамото et al. (2004) that the environmental seasonality controlled by the variation in water level may alter the richness and the abundance of resources in the environment, influencing the food intake and dietary composition of predator fish. During the flood, the rising river level increases the abundance of food derived from the more different sources, providing better conditions for the fish to feed abundantly. In the dry season, the decrease in the water level leads to a scarcity of food (RESENDE et al. 1996). For carnivorous/piscivorous fishes this pattern may be inverted: during the flood stage, fodder fish species disperse over the floodplain in search of different food sources and shelter, which decreases their accessibility to predators. During the dry season, prey concentrate in the restricted water bodies and become more available to potential predators, thus increasing not only the diversity, but also the abundance of these items (Ferreira et al. 2014).

It is of critical importance to understand the mechanisms that regulate the structure of fish assemblages, not only to acquire basic information, but also to anticipate the effect of environmental changes on the integrity of communities. As well as many studies in the Neotropics (e.g., Junk et al. 1983, SAINT-PAUL \& SoAres 1987, Rodrígues \& Lewis 1997, Tejerina-Garro et al. 1998, 
Saint-Paul et al. 2000, Súarez et al. 2001, Hoeinghaus et al. 2003, Siqueira-Souza \& Freitas 2004, Súarez et al. 2004, 2011, Freitas \& Garcez 2004, Freitas et al. 2013), our results suggest that fish assemblages are influenced by seasonal variations and are ruled by the flood pulse, which causes changes in transparency, depth, water current velocity and dissolved oxygen. Although not detected evidence of environment changes associated to the activities of oil extraction, this study represents a baseline for future studies associated with evaluation of eventual or cronic environmental impacts in the area.

\section{ACKNOWLEDGMENTS}

We wish to thank the National Institute for Amazonian Research and in particular J. Zuanon and H.M. Espírito-Santo for their help with the identification of the taxonomic material. T.C. Oliveira for guidance and support in the chemical analysis of the water.

\section{LITERATURE CITED}

Agostinho AA, Thomaz SM, Gomes LC (2005) Conservação da biodiversidade em águas continentais do Brasil. Megadiversidade 1: 70-78.

Albrecht MP, Caramaschi EP, Horn MH (2009) Population responses of two omnivorous fish species to impoundment of a Brazilian tropical river. Hydrobiologia 627: 181-193. doi: 10.1007/s10750-009-9727-7

Chesson PL, Huntly N (1997) The roles of harsh and fluctuating conditions in the dynamics of ecological communities. American Naturalist 150: 520-553.

Clarke KR, Green RH (1988) Statistical design and analysis for a 'biological effects' study. Marine Ecology Progress Series 46: 213-226.

Crampton WGR (1999) Os peixes da Reserva Mamirauá: Diversidade e história natural na planície alagável da Amazônia, p. 10-36. In: Queiroz HL, Crampton WGR (Eds.). Estratégias para Manejo de Recursos Pesqueiros em Mamirauá. Brasília, Sociedade Civil Mamirauá.

Dudgeon DA, Arthington AH, Gessner MO, Kawabata ZI, Knowler DJ, Leveque C, Naiman RJ, Prieur-Richard AH, Soto D, Stiassny MJL, Sullivan CA (2006) Freshwater biodiversity: importance, threats, status and conservation challenges. Biological Review 81: 163-182. doi: 10.1017/\$1464793105006950

EPA (1986) Test methods for evaluating solid waste, physical/ chemical methods; Method 8270C - Semivolatile organic compounds by gas chromatography/masspectrometry. U.S. Environmental Protection Agency. Available online at: http:/ /www.epa.gov/SW-864/main.htm [Accessed: 10/06/2008]

Esteves FA (1998) Fundamentos de Limnologia. Rio de Janeiro, Interciência, 790p.

Ferreira EJG, Zuanon JAS, Santos GM (1998) Peixes comerciais do médio Amazonas: Região de Santarém, Pará. Brasília,
IBAMA, 185p.

Ferreira FS, Vicentin W, Costa FES, Súarez YR (2014) Trophic ecology of two piranha species, Pygocentrus nattereri and Serrasalmus marginatus (Characiformes, Characidae), in the floodplain of the Negro River, Pantanal. Acta Limnologica Brasiliensia 26: 381-391. doi: 10.1590/S2179-975X2014000 400006

Freitas CEC, Garcez RCS (2004) Fish communities of natural channels between floodplain lakes and Solimões-Amazonas river (Amazon-Brazil). Acta Limnologica Brasiliensis 16: $273-280$.

Freitas CeC, Siqueira-Souza FK, Prado Kll, Yamamoto RC, Hurd LE (2010) Fish diversity in Amazonian floodplain lakes. International Journal of Medical and Biological Frontiers 16: $128-142$.

Freitas CEC, Siqueira-Souza FK, Florentino AC, Hurd LE (2013) The importance of spatial scales to analysis of fish diversity in Amazonian floodplain lakes and implications for conservation. Ecology of Freshwater Fish 45: 1-8. doi: 10.1111/eff.12099

Goulding M (1980) The fishes and the forest: Explorations in Amazonian Natural History. Berkeley, University of California Press, 280p.

HAMILTON SK, LeWIS WM (1990) Basin morphology in relation to chemical and ecological characteristics of lakes on the Orinoco River ûoodplain, Venezuela. Archives of Hydrobiology 119: 393-425.

Hammer P, Harper DAT, Ryan PD (2001) PAST: Paleontological statistics software package for education and data analysis. Paleontologia Eletrônica 4: 1-9.

Hoeinghaus DJ, Laymana CA, Albrey Arringtona DA, Winemiller KO (2003) Spatiotemporal variation in fish assemblage structure in tropical floodplain creeks. Environmental Biology of Fishes 67: 379-387.

Jackson DA, Peres-Neto PR, Olden JD (2001) What controls who is where in freshwater fish communities - the roles of biotic, abiotic, and spatial factors. Canadian Journal of Fisheries and Aquatic Sciences 58: 157-170. doi: 10.1139/f00-239

Junk WJ (1983) As águas da Região Amazônica, p. 45-100. In: Salati E, Schubart HOR, Junk WJ, Oliveira AE (Eds.). Amazônia: desenvolvimento, integração e ecologia. São Paulo, Editora Brasiliense.

KARR JR (1981) Assessment of biotic integrity using fish communities. Fish 6: 21-27.

KiKUCHI RM, Uieda VS (1998) Composição da comunidade de invertebrados de um ambiente lótico tropical e sua variação espacial e temporal, p. 157-173. In: Nessimian JL, CARVALHO AL (Eds.). Ecologia de insetos aquáticos. Rio de Janeiro, Série Oecologia Brasiliensis.

Lowe-McConnell RH (1999) Estudos ecológicos em comunidades de peixes tropicais. São Paulo, EDUSP, 524p.

Magurran AE (2003) Measuring Biological Diversity. London, Blackwell Publishing, 264p. 
Nelson JS (2006) Fishes of the World. New Jersey, Wiley, 601p. ReIs RE (2003) Family Callichthyidae, p. 291-309. In: ReIs RE, Kullander SO, Ferraris CJ (Eds.) Checklist of the freshwater fishes of South and Central America. Porto Alegre, EDIPUCRS.

Resende EK, Pereira RAC, Almeida VlL, Silva AG (1996) Alimentação de peixes carnívoros da planície inundável do rio Miranda, Pantanal, Mato Grosso do Sul, Brasil. Corumbá, Embrapa-CPAP, 56p.

Rodríguez MA, Lewis WM (1997) Structure of fish assemblages along environmental gradients in floodplain lakes of the Orinoco River. Ecological Monographs 67: 109-128.

Saint-Paul U, Soares MGM (1987) Diurnal distribution and behavioral responses of fishes to extreme hypoxia in Amazon floodplain lake. Environmental Biology of Fish 20: 91-104.

Saint-Paul U, Zuanon Jas, Correa MaV, Garcia M, Fabré NN, Berger U, Junk WJ (2000) Fish communities in central Amazonian white and blackwater floodplains. Environmental Biology of Fish 57: 235-250.

Santos G, Ferreira E, Zuanon JAS (2006) Peixes Comerciais de Manaus. Manaus, INPA, 144p.

Silvano RAM, Amaral BD, Oyakawa OT (2000) Spatial and temporal patterns of diversity and distribution of the Upper Juruá River fish community (Brazilian Amazon). Environmental Biology of Fish 57: 25-35. doi: 10.1023/A:1007594510110

Siqueira-Souza FK, Freitas CEC (2004) Fish diversity of floodplain lakes on the lower stretch of the Solimões river. Brazilian Journal of Biology 64: 501-510. doi: 10.1590/S151969842004000300013

Soares MGM, Junk WJ (2000) Commercial fishery and fish culture of the state of amazonas: status and perspectives, $p$.
433-461. In: Junk WJ, Ohly JJ, Piedade MTF, Soares MGM (Eds.). The Central Amazon Floodplain: actual use and options for a sustainable management. Leiden, Backhuys Publishers.

Stewart JD, Ibarra M, Barriga-Salazar R (2002) Comparison of deep-river and adjacent sandy-beach fish assemblages in the Napo river basin, eastern Ecuador. Copeia 2: 333-343.

Súarez YR, Petrere Jr M, Catella AC (2001) Factors determining the structure of fish communities in Pantanal lagoons (MS, Brazil). Fisheries Management and Ecology 8: 173-186.

Súarez YR, Petrere Jr M, Catella AC (2004) Factors regulating diversity and abundance of fish communities in Pantanal lagoons, Brazil. Fisheries Management and Ecology 11: 45-54.

Súarez YR, Souza MM, Ferreira FS, Pereira MJ, Silva EA da, Ximenes LQL, Azevedo LG de, Martins OC, Lima Júnior SE (2011) Patterns of species richness and composition of fish assemblages in streams of the Ivinhema River basin, Upper Paraná River. Acta Limnologica Brasiliensia 23: 177-188.

Tejerina-Garro FL, Fortin R, Rodriguéz MA (1998) Fish community structure in relation to environmental variation in floodplain lakes of the Araguaia River, Amazon Basin. Environmental Biology of Fishes 51: 399-410.

WinemiLler KO (1989) Patterns of variation in life history among South American fishes in seasonal environments. Oecologia 81: 225-241.

WoldA H (1981) Similarity indices, sample size and diversity. Oecologia 50: 296-302.

Yamamoto KC, Soares MGM, Freitas CEC (2004) Alimentação de Triportheus angulatus (Spix \& Agassiz, 1829) no lago Camaleão, Manaus, AM, Brasil. Acta Amazonica 34: 653-659.

Appendix 1. Numerical abundance and biomass data of the species collected during the flood and (drought) seasons in the Urucu River, Municipality of Coari - AM/Brazil.

\begin{tabular}{|c|c|c|}
\hline Taxa & Abundance & Biomass (g) \\
\hline \multicolumn{3}{|l|}{ Osteoglossiformes } \\
\hline \multicolumn{3}{|l|}{ Osteoglossidae } \\
\hline Osteoglossum bicirrhosum (Cuvier,1829) & $0(55)$ & $0(45506)$ \\
\hline \multicolumn{3}{|l|}{ Clupeiformes } \\
\hline \multicolumn{3}{|l|}{ Pristigasteridae } \\
\hline Pellona castelnaeana (Valenciennes, 1847) & $32(0)$ & $14235(0)$ \\
\hline Pellona flavipinnis (Valenciennes, 1836) & 22(4) & $7355(1985)$ \\
\hline \multicolumn{3}{|l|}{ Engraulidade } \\
\hline Lycengraulis batesii (Günther, 1868) & $7(1)$ & $385(25)$ \\
\hline \multicolumn{3}{|l|}{ Beloniformes } \\
\hline \multicolumn{3}{|l|}{ Belonidae } \\
\hline Potamorrhaphis guianensis (Jardine, 1843) & $1(0)$ & $40(0)$ \\
\hline \multicolumn{3}{|l|}{ Characiformes } \\
\hline \multicolumn{3}{|l|}{ Acestrorhynchidae } \\
\hline Acestrhorhynchus falcirostris (Cuvier, 1819) & $1(28)$ & $0(4289)$ \\
\hline Acestrorhynchus falcatus (Bloch, 1794) & $3(0)$ & $700(0)$ \\
\hline Acestrorhynchus microlepis (Schomburgk, 1841) & $1(0)$ & $115(0)$ \\
\hline
\end{tabular}


Appendix 1. Continued

\begin{tabular}{|c|c|c|}
\hline Taxa & Abundance & Biomass (g) \\
\hline \multicolumn{3}{|l|}{ Agoniatidae } \\
\hline Agoniates halecinus (Müller \& Troschel, 1845) & $11(14)$ & $510(505)$ \\
\hline \multicolumn{3}{|l|}{ Anostomidae } \\
\hline Abramites hypselonotus (Günther, 1868) & $0(2)$ & $0(75)$ \\
\hline Leporinus agassizi Steindacherner, 1876 & $14(16)$ & $5300(5920)$ \\
\hline Leporinus fasciatum (Bloch, 1794) & $3(2)$ & $810(270)$ \\
\hline Schizodon fasciatus Spix \& Agassiz, 1829 & $0(1)$ & $0(585$ \\
\hline Rhytiodus argenteofuscus Kner, 1858 & $3(0)$ & $710(0)$ \\
\hline \multicolumn{3}{|l|}{ Characidae } \\
\hline Brycon cf. pesu Müller Troschel, 1845 & $16(6)$ & $1210(55)$ \\
\hline Brycon melanopterus (Cope, 1872) & $0(4)$ & $0(800)$ \\
\hline Bryconops alburnoides (Kner, 1858) & $64(5)$ & $2195(145)$ \\
\hline Bryconops caudomaculatos (Günther, 1864) & $8(1)$ & $235(45)$ \\
\hline Chalceus erythrurus (Cope, 1870) & 2(19) & $145(1370)$ \\
\hline Moenkhausia lepidura (Kner, 1858) & $14(5)$ & $245(180)$ \\
\hline Myleus rubrypinnis (Müller \& SchomburgK, 1841) & $4(5)$ & $1045(465)$ \\
\hline Myleus sp. & $1(0)$ & $135(0)$ \\
\hline Mylesinus schomburgkii Valenciennes, 1850 & $1(0)$ & $745(0)$ \\
\hline Poptella brevispina Reis, 1989 & $1(0)$ & $35(0)$ \\
\hline Pristobrycon striolatus (Steindachner, 1908) & $6(0)$ & $935(0)$ \\
\hline Pygocentrus nattereri Kner, 1858 & $12(5)$ & $1830(1330)$ \\
\hline Serrasalmus altispinis Merckx, Jégu \& Santos, 2000 & $0(2)$ & $0(320)$ \\
\hline Serrasalmus sp. & $0(6)$ & $0(7775)$ \\
\hline Serrasalmus rhombeus (Linnaeus, 1766) & $54(44)$ & $11680(245)$ \\
\hline Tetragonopterus chalceus Spix \& Agassiz, 1829 & $1(0)$ & $90(0)$ \\
\hline Triportheus albus Cope, 1872 & $16(6)$ & $570(645)$ \\
\hline Triportheus angulatus (Spix \& Agassiz, 1829) & $0(7)$ & $0(678)$ \\
\hline Triportheus elongatus (Günther, 1864) & $1(0)$ & $150(0)$ \\
\hline \multicolumn{3}{|l|}{ Chilodontidae } \\
\hline Caenotropus labyrinthicus (Kner, 1858) & 2(9) & $240(80)$ \\
\hline \multicolumn{3}{|l|}{ Ctenoluciidae } \\
\hline Boulengerella cuvieri (Agassiz, 1829) & $2(0)$ & $630(0)$ \\
\hline Boulengerella maculata (Valenciennes, 1850) & $3(22)$ & $410(3729)$ \\
\hline \multicolumn{3}{|l|}{ Curimatidae } \\
\hline Curimata cf. cisandina (Allen, 1942) & $1(0)$ & $95(0)$ \\
\hline Curimata inornata Vari, 1989 & $0(33)$ & $0(2195)$ \\
\hline Curimata vittata $($ Kner, 1858) & 1(3) & $135(200)$ \\
\hline Cyphocharax notatus (Steindachner, 1908) & $0(2)$ & $0(70)$ \\
\hline Psectrogaster amazonica Eigenmann \& Eigenmann, 1889 & $1(0)$ & $150(0)$ \\
\hline Psectrogaster rutiloides (Kner, 1858) & $4(0)$ & $590(0)$ \\
\hline Steindachnerina bimaculata (Steindachner, 1876) & $0(1)$ & $0(95)$ \\
\hline \multicolumn{3}{|l|}{ Cynodontidae } \\
\hline Cynodon gibbus Spix \& Agassiz, 1829 & $3(0)$ & $260(0)$ \\
\hline Raphiodon vulpinus Spix \& Agassiz, 1829 & $5(0)$ & $2440(0)$ \\
\hline \multicolumn{3}{|l|}{ Erytrinidae } \\
\hline Hoplias malabaricus (Bloch, 1794) & 1(9) & $40(400)$ \\
\hline \multicolumn{3}{|l|}{ Hemiodontidae } \\
\hline Hemiodus semitaeniatus (Kner, 1858) & 2(6) & $150(390)$ \\
\hline Hemiodus unimaculatus (Bloch, 1794) & $7(36)$ & $900(3745)$ \\
\hline Anodus orinocensis (Steindachner, 1887) & $1(0)$ & $145(0)$ \\
\hline
\end{tabular}


Appendix 1. Continued.

\begin{tabular}{|c|c|c|}
\hline Taxa & Abundance & Biomass (g) \\
\hline \multicolumn{3}{|l|}{ Siluriformes } \\
\hline \multicolumn{3}{|l|}{ Loricariidae } \\
\hline Ancistrus sp. & $0(1)$ & $0(35)$ \\
\hline Dekeyseria amazonica (Rapp Py-Daniel, 1985) & $1(0)$ & $95(0)$ \\
\hline Loricaria cataphracta Linnaeus, 1758 & $0(1)$ & $0(20)$ \\
\hline Rineloricaria sp. & $0(4)$ & $0(100)$ \\
\hline Sturisoma sp. & $0(2)$ & $0(100)$ \\
\hline Hypoptopoma cf. gulare Cope, 1878 & 24(1) & $170(20)$ \\
\hline \multicolumn{3}{|l|}{ Auchenipteridae } \\
\hline Ageneiosus brevifilis (Linnaeus, 1766) & $1(0)$ & $375(0)$ \\
\hline Ageneiosus gr. vittatus (Steindachner, 1908) & $1(0)$ & $10(0)$ \\
\hline Auchenipterichthys sp. & $2(0)$ & $30(0)$ \\
\hline Auchenipterus ambyacus (Fowler,1915) & $2(0)$ & $70(0)$ \\
\hline Auchenipterus nuchalis (Spix \& Agassiz, 1829) & $2(0)$ & $205(0)$ \\
\hline Centromochus heckelli (De Felippi, 1853) & $2(0)$ & $35(0)$ \\
\hline Parauchenipterus galeatus (Linnaeus, 1758) & $5(0)$ & $200(0)$ \\
\hline Tatia intermedia (Steindachner, 1877) & $2(0)$ & $70(0)$ \\
\hline \multicolumn{3}{|l|}{ Callichthyidae } \\
\hline Dianema urostriatum (Miranda Ribeiro, 1912) & 63(0) & 1030(0) \\
\hline \multicolumn{3}{|l|}{ Pimelodidae } \\
\hline Calophysus macropterus (Lichtenstein, 1819) & $28(15)$ & $7230(325)$ \\
\hline Hemisorubim platyrhynchos (Valenciennes, 1840) & $0(8)$ & $0(5022)$ \\
\hline Hypophtalmus edentatus Spix \& Agassiz, 1829 & $2(0)$ & $533(0)$ \\
\hline Hypophtalmus marginatus Valenciennes, 1840 & $2(0)$ & 195(0) \\
\hline Pimelodus blochii (Valenciennes, 1840) & $5(4)$ & $490(285)$ \\
\hline Pinirapus pirinanpus (Spix \& Agasiz, 1829) & $4(0)$ & $1320(0)$ \\
\hline Pseudoplatystoma fasciatum (Linnaeus, 1766) & $1(0)$ & 1085(0) \\
\hline Sorubim lima (Bloch \& Schneider, 1801) & $4(0)$ & $550(0)$ \\
\hline \multicolumn{3}{|l|}{ Perciformes } \\
\hline \multicolumn{3}{|l|}{ Cichlidae } \\
\hline Biotodoma cupido (Heckel, 1840) & $0(6)$ & $0(155)$ \\
\hline Chaetobranchus flavenscens Heckel, 1840 & $0(7)$ & $0(1580)$ \\
\hline Cichla sp. & $0(10)$ & $0(1760)$ \\
\hline Cichla monoculus (Spix \& Agassiz, 1831) & $0(2)$ & $1765(225)$ \\
\hline Crenicinchla cincta Regan, 1905 & $1(0)$ & $460(0)$ \\
\hline Geophagus proximus (Castelnau, 1855) & $0(9)$ & $0(1185)$ \\
\hline Satanoperca Jurupari (Heckel, 1840) & $0(1)$ & $0(190)$ \\
\hline \multicolumn{3}{|l|}{ Scianidae } \\
\hline Plasgioscion squamosissimus (Heckel, 1840) & $8(6)$ & $2340(1140)$ \\
\hline \multicolumn{3}{|l|}{ Pleuronectiformes } \\
\hline \multicolumn{3}{|l|}{ Achiridae } \\
\hline Hypoclinemus mentalis (Günther, 1862) & $0(1)$ & $0(30)$ \\
\hline
\end{tabular}

Submitted: 3 December 2014

Received in revised form: 22 June 2015

Accepted: 6 October 2015

Editorial responsibility: Vinicius Abilhoa 